\title{
Sexual Issues and Prevention Through Sex Education in Primary School
}

\author{
Ana Andriani, Badarudin \\ Program Studi PGSD FKIP, Universitas Muhammadiyah Purwokerto, Purwokerto, Indonesia \\ Corresponding e-mail: ana.andriani@gmail.com
}

\begin{abstract}
Sex education in schools is needed to meet the needs of students' knowledge related to the character of anatomy. Elementary school students acquire knowledge about sex education. However, sex education should be given the appropriate development of their age. Social phenomenon shows that the proliferation of deviant behavior particularly against children of elementary school age students, should be addressed wisely by all components of society. Protection against both physical and psychological students should be pursued in earnest. School as one of the educational institutions are expected to meet the educational needs of their students in various science. Sex education is required in order to give a better understanding to students so that students are able to know and understand the things that can be done or should not do. Vigilance in providing an understanding of the sexual area also should be done so as not to cause misunderstanding. In the environment of the general public, a study of the sexual sphere is still considered taboo, especially notify children. However, that does not mean sex education should not be given to them, because even when the child does not know about the things pertaining to this issue, then the big questions will arise and the fear is that they are looking for answers themselves the wrong way. Complex problems in society as a result of globalization need to watch together. Rush of information coming from a variety of print and electronic media are not all positive. Much of the information received by the students so not worth unknown. Including sites that are not suitable for consumption, especially public elementary school students. The need for preventive measures to anticipate unwanted things happen to elementary school students. Various attempts were made in order not to cause suspicion, so that they are able to run their daily lives normally, without any interruption. Therefore, sex education in primary schools is one way out. What is the sex education, how the learning process, anyone can be involved in its implementation? What should be prepared? Related to sex education will be discussed in this paper.
\end{abstract}

Keywords: Sex education, elementary school students

\section{INTRODUCTION}

Globalization makes many changes in various aspects of human life. Ideological, political, economic, social, cultural, defense and security does not escape from these changes. Even the world of education is very important for the sustainability of human beings to be more civilized. Advantages and disadvantages as the effects of globalization can be felt directly or indirectly by human beings. This should be an attention to all components of society. Globalization makes steps should be accelerated with the development of science and information technology. This must be done immediately, because if not, it will be behind the others. Tilar (Abdulhak, 1998: 1), borrow opinion of Rousseau in his book, turbulance in World Politics, identified five sources of the globalization process, which consists is:

1) Globalization caused by the dynamics of global technologies that reduce the distance as well as rapid human motion;

2) Globalization arising from the troubles in this world, such as environmental concerns and population issues;

3) The process of globalization as a result of the emergence of the country's ability to solve social problems;

4) The emergence of sub-groups, the stronger the community of nations; and

5) As a result of the increasing globalization of expertise, education, and the problems beyond its borders. 
The statement is an example of the impact of globalization, which have a major impact on the attitude and behavior change in people's lives. The world of education is also affected by globalization. Science and technology are also positive and negative impacts. Including in the education from the basic level to the college level.

Education as a conscious and systematic effort to develop human potentials in accordance with the Education Law No. 20 of 2003, is expected to be a filter to the negative, so it will not affect to their behavior. Also in health education. Health is an important thing for humans. Human can not do their activities, when their physical is not well. Therefore, we must understand about the importance about health.

Sex education is also needed to provide knowledge related to human anatomy. A good understanding of knowledge about sex for students should be able to anticipate things that are not desirable. To this purpose, the required sex education in schools adjusted to their developmental age. As well in the United States in 2011, the National Sexuality Education Standards (NSES) developing a framework related to sex education adjusted to their ages, from kindergarten to grade 12 . In $2012,42 \%$ of primary schools have a specific time for health education (Centers for Disease Control and Prevention, 2013). This means that in the bottom half of the primary schools teach health covering several topics of health education, including sex education. (Fisher: 2015).

School, became the second after the family environment, and teachers are the true parents. AlGhazali (Iqbal, 2013: 112) which has the task of guiding, directing and educating children not only until adulthood even more than that, which has the task of guiding, directing and educating children not only until adulthood even more than that. Education of children at specific hours handed over to the schools and teachers as the spearhead of education. Certainly teachers can not always educate, train, and guide and teach students. There are limitations of time, place and amount to implement them. However, it is expected of teachers and other school devices can provide a sense of comfort and security to the students and always need to be aware of things that are deviant who would harm them.

\section{DISCUSSION}

\subsection{Sex education in elementary school}

Education is a force. Brameld (1965: 1) in Education as a Power, outlines the importance of education in human life. A conscious effort and carried out systematically in order to develop children's potential for a more civilized life. This is an important activity that can not be done arbitrarily. When this is not done seriously, it is feared things happen that are not desirable. Negative behaviors that often appears as a social phenomenon which allegedly is not good education. It is very unfortunate when children or students as the future generation does not have a good understanding of the life they lead.

Physical and spiritual health is also very important for human life. Can one not do business with the optimal when the physical condition is not in a healthy state? Likewise with the spiritual health, is expected to continue in a healthy condition. Treatment for physical and spiritual make healthy should be done in a balanced way. In health education, there is a sex education that can be given to children of students, so that they have a good understanding of anatomy, and know what things that can and can not do to the body. As in life there was something unusual (deviant behavior) of course have to watch out together by conducting preventive measures so as not to cause harm to the students.

Psychology says, there deviant behavior that needs to be watched. Behavior deviant behavior can be regarded as a psychological problem (mental illness) as well as social problems. The character of a person who has a tendency deviation of sexual behavior should be treated as normal human beings, not isolated, but also receive preferential treatment. Society should not tolerate such deviant behavior. Besides be contagious to other people, it can also make changes in the behavior and attitudes of people who become victims.

\subsection{Sex education for elementary school}

Research Rogers and Rogers in Reiss and Halstead (2004: 98) explains that the children are "sexual beings". This term is in line with their interest in sexual materials due to the conflict raised by adults. On one side, they are often not able to run from sexual image, on the other side the adults hide it. Sex is also one of the basic human needs. As a basic requirement, sex education is very necessary to 
anticipate the things undesirable. Sex education can be given to students based on developmental age:

a. Age of the children (1-5 years)

Introducing sex organs possessed like, explain the other limb. Including descriptions of the functions and how to protect them.

b. Elementary school age (6-10)

Understanding the sex differences (male and female) to inform the origin of man, cleaning the genitals properly to avoid germs and disease.

c. Towards Youth

Explain puberty and its characteristics, as well as receiving a change of shape.

d. Young age

Giving an explanation of harmful from sexual behavior such as promiscuity. Instill morals and principles 'Say no' to premarital sex and to build acceptance of self.

\subsection{Benefits of Sex Education in Primary School Children. Which is:}

1) Understand the role of gender

Sex education in children is expected to provide a good understanding. So they have a strong character not to be tempted things that are negative. A boy is expected to grow and develop into complete man, as well as girls, are expected to grow and develop into a complete woman. So that no longer are uncomfortable with the role gender.

2) Receive any physical changes experienced.

Childhood is a period where a man is experiencing growth and development, both physically and psychologically. Especially when they start puberty, where the physical and psychological changes experienced the most rapid phase. Given sexuality education make the children know and understand about how they respond to these changes, so they will not feel strange, shocked, confused, and scared when deal with it

3) Removing curiosity that is not healthy

Instead, people nearby such as parents and teachers can be a figure of fun for children to be able to meet a passionate curiosity about many things, including about sexuality. It is meant, so that the child does not decide to seek out answers to the questions through a friend, comic, VCD (Video Compact Disc), or other media that did not ensure children get the correct information

4) Strengthen the confidence and responsible Confident will arise if children is comfortable with himself. Children will feel comfortable if they know every part of him, is also a function of the parts. Thus, the child will know what should and should not do. Eventually, the child will begin to learn to take responsibility for himself.

5) Know and understand the enormity of the power of the Creator

An understanding of the parts and functions that exist in the body will make the children get to know and understand how extraordinary the creation of Allah SWT.

The family is the main factor forming a child's personality to become a figure. Because of the child's family environment started to learn about him, shaping him into someone who has a view of themselves. Through cooperation between parents with various parties. Teacher as supervisor for the child while at school. Although there are many people who have helped anticipate this problem, parents can not hands off immediately granted. Again, parents are expected to become a supporting figure, filters, and amplifiers to what the child has learned from those who have helped. For that, we need good cooperation between parents with various supporting elements, so that children fully developed and optimally.

\subsection{The Importance of Sex Education in Elementary School Children}

Children and adolescents are vulnerable to misinformation about sex. If they did not get the proper sex education, they will be consumed myths about sex that is not true. Information about sex should be obtained directly from parents who have special concern for their children. The survey results of the National Family Planning Coordinating Board (BKKBN) shows that more than 60 percent of teens in Indonesia have premarital sex. The reason for the lack of sex education to children and adolescents.

Sex education was considered taboo actually have a negative impact on children. Instead, sex should be taught to children in a way that is wise. Sex education is a teaching efforts, awareness, and providing information about sexual problems. The information provided in whom knowledge of the functioning of reproductive organs by instilling morals, ethics, commitment, religion to prevent "abuse" of the reproductive organs.

Sex education can be regarded as the forerunner of family life education. Sex education has a very important meaning. The psychologists recommend that children from an early age should begin to be introduced to sex education in accordance with their maturity stage of development. Information about sex can be given since the child can perform twoway communication, parents today need to be 
equipped with knowledge about sex, because not infrequently also the children who asked to be the subject of sex. The lack of briefing about sex makes children become confused and can look for information is wrong, because the original source is not feasible. The end of the result is certainly not in line with expectations and benefits.

Parents should have no doubt about the importance of early sex education. Eliminate awkward feeling that exists and start to develop sensitivity towards sex education to children. If it does not start early it will be more dangerous if the child is a teenager. The teens can seek sex-related information through various sources such as books, magazines, movies, the internet with ease.

Information gained is not necessarily true and may even be misleading. Therefore, parents are advised to begin to familiarize dialogue with children, and can also use their parents as a trusted resource.

\subsection{Theoretical Interest in Sex Education:}

1) Sex education in schools can help children understand the impact of sex in their lives. So, free sex among teenagers can be solved by giving and broaden their knowledge of the dangers.

2) Sex education also answered all the questions that exist in their minds as to the changes that occur in their bodies.

3) Sexual harassment is rife throughout the world. So, sex education can take an active role in dealing with the problem of abuse and sexual harassment.

4) Knowledge about sex they get from the school will be much better than should let them seek their own information about sex and pornographic material from the internet. Because sometimes the information they can on the internet it will only mislead them and made the wrong understanding.

\subsection{Sex Education Material given in elementary school (SD) Mainly grade 5-6}

The material is given to elementary school students related to sex education begins with openness to parents, guidance will be their perceptions about sex that it refers to the sex and not about things outside of it (the relationship of men and women, create a child process etc.). Furthermore, the differences between men and women, the introduction of body organs and functions. using language must be good and true about sex using scientific language, such as 'penis', 'Vagina', introduction of the system of sex organs simply, introduction of Anatomy of the reproductive system simply, how to care for the health and hygiene of organs including the reproductive organs, to teach children to cherish and protect her own body, the process of pregnancy and childbirth is simple, prepare children to enter puberty, physical and psychological development that occurs in adolescents, a hallmark of sexuality primary and secondary, until the process of wet dreams, as well as the process of ovulation and menstruation is simple.

Provide an understanding students on sexual education for students to have a positive attitude and behavior are responsible for reproductive health in general.

\subsection{The submission of Sex Education in Elementary School Children}

Delivery of material about sex education to children can begin to teach them to clean their own genitals. Teach children to clean their genitals properly after urinating (BAK) or defecate (BAB), it is very important that children are not dependent on others and more self-sufficient. Another important point of this study is that the children are indirectly taught to not carelessly allow others to clean his genitals.

Anatomy becomes the initial stages for the introduction of sex in children. Furthermore, the gradual education of how living things reproduce, as in humans. The role of a parent is required to be able to explain to their children about the impact that would be acceptable if the children do deviate action. Mechanical delivery also should not vulgar, fearing they would have a negative impact on children. Do not forget the age factor to deliver it. That is when it will teach children about sex education, see the intended target. Because when children are taught about sex, the child will be critical and were curious about everything.

Delay to give sex education when the child is not recommended, it is feared late, especially the child was a teenager. Globalization as the current era in which information is so easily accessible with friends, feared children already know more about sex and most probably from the wrong viewpoint. The way that can be used to introduce the body and body characteristics, among others through media images or posters, songs and games. Understanding 
of sex education at an early age is expected that children can get proper information about sex. This is because the other media that can teach children about sex education, namely media information. So that children can get incorrect information from the mass media, especially television shows that less educated.

Early sex education would avoid pregnancy outside marriage when children grow into adolescence and adulthood, according to research later. No need to be taboo to talk about sex in the family. Because your child needs to get the right information from the parents, not from other people about sex. Curiosity, became a concern when children are not equipped with sex education, then the child will seek answers from others, and it would be scary if sex information obtained from peers or the Internet that information may be wrong. Protect your children from an early age by providing them education about sex in a proper way.

Sexual education in addition to explain about aspects of anatomical and biological also explains about the psychological aspects and moral.

Proper sex education should include elements of human rights. Also the values of culture and religion be included so that the child will have a good character and morals.

\section{CONCLUSIONS}

Education is an important element in human life, in addition to other aspects such as political, economic, social, cultural and defense and security. Education also will make human dignity, or not. In its implementation, education must also meet physical and spiritual needs so that the balance between the two occurred. Sex education as part of health education is a lesson that can be given to children from since early. It is intended to allow children to have complete knowledge and a solid understanding of things related to anatomy. The child will know what to do and not do to his body. The wrong treatment for their bodies feared will lead to deviant behavior. Sex education should be provided in accordance with the development of their age.

Concern for the future generation in order to avoid unwanted actions should be pursued maximum. One of them is the sex education given by teachers at school. Sex education should be fully and correctly so that children are understand. Besides parents as partners teacher should also be able to provide sex education at home. The phenomenon is rampant these days are expected to no longer appears to the detriment of the younger generation. A normal life is the desire of all the children of mankind, including the younger generation of the children of the people who will someday replace the role of parents in achieving its goals.

\section{REFERENCES}

Al-Qur'anul Kariim

Abdulhak, H. I. (1998). Landasan Sosiologi Pendidikan (Bunga Rampai).

Bandung: IKIP Bandung Press

Brameld, T. (1965). Education as Power, USA: Library of Congress

Fisher, C et.al (2013) Perseptions of Elementary School Children's Parents Regarding Sexuality Education dalam American Journal Sexuality Education. ISSN: 1554-6128 print / 1554-6136 online DOI: 10.1080/15546128.2015.1009595

Halstead. J.Mark, Reiss Michael (2004) Sex Education, Nilai dalam Pendidikan Seks bagi Remaja dari Prinsip ke Praktek. Yogyakara: Alenia Press

Iqbal, A.M. (2013). Konsep Pemikiran Al-Ghazali tentang Pendidikan, Madiun: Jaya Star Nine

Undang-Undang Dasar 1945 Amandemen ke II (2000)

Hurlock B. Elizabeth. Perkembangan Anak 155-192, Penerbit Erlangga Jakarta, 1978

Soejanto Agoes, Drs., Psikologi Perkembangan 4659, Rineka Cipta Jakarta, 2005.

Lickona Thomas. Pendidikan Karakter 103-134, Kreasi Wacana Bantul, 2012.

https://pemikiranislam.wordpress.com/2007/08/11/p andangan-terhadap-kaum-homoseksual-danlesbian/ accessed on 15 April 2016

http://www.republika.co.id/berita/jurnalismewarga/wacana/16/02/03/o1yie3394-lgbt-dalamperspektif-hukum-islam accessed on 15 April 2016

http://www.hidayatullah.com/artikel/opini/read/2016 /02/04/88712/lgbt-dalam-perspektif-hukumislam-2.html accessed on 15 April 2015

http://www.muslimedianews.com/2016/02/lgbtdalam-perspektif-ham-dan-hukum.html

accessed on 15 April 2015

http://indonesian.irib.ir/islam/al-quran/item/73057Tafsir_Al-Quran,_Surat_Hud_Ayat_79-83 accessed on 25 April 2016

http://jadiberita.com/55472/story-alan-turingpencipta-awal-komputer.html accessed on 25 April 2016

http://islamidinah26.blogspot.co.id/2015/03/penerap an-pendidikan-seks-pada-anak.html accessed on 25 April 2016 
https://pemikiranislam.wordpress.com/2007/08/11/p andangan-terhadap-kaum-homoseksual-danlesbian/ accessed on 15 April 2016

http://www.republika.co.id/berita/jurnalismewarga/wacana/16/02/03/o1yie3394-lgbt-dalamperspektif-hukum-islam accessed on 15 April 2016

http://www.hidayatullah.com/artikel/opini/read/2016 /02/04/88712/lgbt-dalam-perspektif-hukumislam-2.html accessed on 15 April 2015

http://www.muslimedianews.com/2016/02/lgbtdalam-perspektif-ham-dan-hukum.html accessed on 15 April 2015

http://indonesian.irib.ir/islam/al-quran/item/73057Tafsir_Al-Quran,_Surat_Hud_Ayat_79-83 accessed on 25 April 2016

http://jadiberita.com/55472/story-alan-turingpencipta-awal-komputer.html accessed on 25 April 2016

http://islamidinah26.blogspot.co.id/2015/03/penerap an-pendidikan-seks-pada-anak.html accessed on 25 April 2016 